\title{
BARIERY BIBLIJNE INKLUZJI OSÓB Z NIEPEŁNOSPRAWNOŚCIĄ WE WSPÓLNOTACH CHRZEŚCIJAŃSKICH
}

\begin{abstract}
Streszczenie: Celem artykułu jest wskazanie na niektóre teksty biblijne, które mogą przyczyniać się do wznoszenia barier utrudniających pełną inkluzję osób z niepełnosprawnością we wspólnotach chrześcijańskich. W Piśmie Świętym postrzega się często niepełnosprawność jako powód do wykluczenia ze wspólnoty kultycznej, efekt ludzkiej winy i grzeszności lub okazję do uszlachetnienia człowieka, ewentualnie - jako impuls do podejmowania działalności charytatywnej przez wspólnotę. W każdym z tych przypadków pozycja osoby z niepełnosprawnością jest postrzegana jako nie-zwyczajna. Jeśli odczytuje się teksty biblijne powierzchownie, istnieje niebezpieczeństwo odmawiania osobom dotkniętym niepełnosprawnością dojrzałej relacji z Bogiem i pełnego uczestnictwa w życiu wspólnoty. Autor postuluje rozwijanie teologii, w której doceniano by szczególny wkład osób z niepełnosprawnością w życie chrześcijańskiej wspólnoty i przyznawano by im miejsce nie na jej obrzeżach, lecz w centrum.
\end{abstract}

Słowa kluczowe: niepełnosprawność; modele niepełnosprawności; inkluzja; wspólnoty chrześcijańskie; teologia niepełnosprawności.

W oficjalnych dokumentach kościołów chrześcijańskich (np. Dokument Stolicy Apostolskiej na Międzynarodowy Rok Osób Upośledzonych), w podejmowanych przez nie inicjatywach, inkluzja osób z niepełnosprawnością jawi się jako oczywistość. Praktyki wspólnot w tym względzie, zwłaszcza z obszaru języka angielskiego, są szeroko dyskutowane i komentowane, choćby na łamach „Journal of Religion, Disability and Health", czasopisma wydawanego przez University of Notre Dame w Indianie. Pozytywne przykłady postaw inkluzyjnych zanotowano np. w Australii, gdzie jedna piąta kościołów chrześcijańskich kładzie mocny akcent na rozwijanie kultury inkluzji osób z niepełnosprawnością, w przekonaniu iż parafia, gmina, zbór, w których brakuje osób z upośledzeniem, jest sama upośledzona (Healey i in. 2013). Niestety, już w przypadku dopuszczania osób z niepełnosprawnością do sakramentu Wieczerzy Pańskiej/Eucharystii pojawiają się ograniczenia - zwłaszcza 
w odniesieniu do wiernych z mocno zawężoną świadomością i trudnościami komunikacyjnymi, nie mówiąc o dopuszczaniu ich do piastowania kościelnych urzędów: przepowiadania słowa i sprawowania sakramentów. Wystarczy przypomnieć, że głuchoniemym zezwolono przyjmować chrzest w Kościele Rzymskokatolickim, czyli stawać się chrześcijanami (a potem również przyjmować inne sakramenty) dopiero w roku 1571 (Liedtke 1996).

Ukazuje się wiele tekstów na temat przesłania, jakie osoby z niepełnosprawnością słyszą $\mathrm{z}$ ambony w rozmaitych wspólnotach kościelnych, jak również na temat nowych propozycji odczytywania tekstów biblijnych odnoszących się do niepełnosprawności (Gaventa 2016; Yong 2011). Niestety, z amerykańskich doniesień wynika, że tematyce niepełnosprawności poświęca się niewiele miejsca w kształceniu duchownych w seminariach i szkołach teologicznych (Annandale, Carter 2014), przez co wielu księży i pastorów nie wie, jak mówić o niepełnosprawności. Brakuje polskich badań na ten temat, ale można przypuszczać, że sytuacja w naszym kraju nie jest pod tym względem znacząco inna.

Celem niniejszego artykułu jest wskazanie na niektóre biblijne teksty odczytywane we wspólnotach chrześcijańskich, które mogą przyczyniać się do wznoszenia mentalnych barier utrudniających pełną inkluzję osób z niepełnosprawnością w społecznościach wierzących. Te teksty oraz towarzyszące im niekiedy bezrefleksyjne głoszenie słowa mogą owe osoby nie tylko narazić na ostracyzm społeczny, ale je same przekonać, iż pozostają wykluczone z horyzontu powszechności i równości nakreślonego przez Apostoła Pawła, który pisał: „Nie ma już Żyda ani poganina, nie ma już niewolnika ani człowieka wolnego, nie ma już mężczyzny ani kobiety, wszyscy bowiem jesteście kimś jednym w Chrystusie Jezusie” (Gal 3, 28).

Zanim przyjrzymy się tekstom biblijnym, które mogą przyczynić się do tworzenia barier w inkluzji osób z niepełnosprawnością, celowe wydaje się przypomnienie różnych modeli jej postrzegania, gdyż są one istotnym czynnikiem w kształtowaniu podejścia do niepełnosprawnych. Najczęściej wyróżnia się trzy główne modele, czyli umysłowe reprezentacje zjawiska niepełnosprawności: biomedyczny (medyczny), funkcjonalny (interakcyjny) oraz społeczny (socjopolityczny) (Wiliński 2010).

\section{Model medyczny}

W przypadku modelu medycznego ujmuje się niepełnosprawność przez pryzmat choroby oraz deficytu. Niepełnosprawność byłaby „stanem”, który wymaga adekwatnego „leczenia”, podobnym do choroby w tym sensie, że ma charakter czasowy i uleczalny. W tym ujęciu medycyna byłaby zdolna do inwazyjnego „naprawienia” nieprawidłowego stanu biologicznego, jeśli nie obecnie, to na pewno w przyszłości - ze względu na rozwój metod leczniczych (Wiliński 2010).

Możliwość zmiany sytuacji osoby z niepełnosprawnością spoczywa zatem w rękach profesjonalistów. Istotne, że w modelu medycznym niepełnosprawność jest postrzegana - choć nie zawsze explicite - jako fenomen czysto negatywny: nie 
może z niej wyniknąć nic pozytywnego, a ewentualne zadowolenie z życia osoby dotkniętej niepełnosprawnością jest wykluczone. Model ten przyczynia się do stygmatyzacji i stereotypizacji osób z niepełnosprawnością jako ludzi dotkniętych pewnym brakiem. W tej perspektywie, jeśli ktoś np. zawiera związek małżeński z osobą z niepełnosprawnością, to mówi się o nim, że jest prawdziwie „świętym” albo „męczennikiem”, gdyż trudno sobie wyobrazić, że partner z niepełnosprawnością miałby wnosić coś pozytywnego do małżeństwa (Nelson i in. 2017).

\section{Model społeczny}

W modelu społecznym niepełnosprawność jest postrzegana jako izolacja i wykluczenie z pełnej partycypacji (aktywności) społecznej osób z ograniczeniami sprawności przez opresyjne społeczeństwo (Wiliński 2010). Niepełnosprawność jest jedynie społecznym konstruktem, będącym efektem niedostępności środowiska, a w szczególnie barier wznoszonych przez „upośledzające” społeczeństwo, kierujące się stereotypami. Tymczasem - jak twierdzą zwolennicy tego modelu - niepełnosprawność to normalna część całego spektrum różnic występujących w społeczeństwie (Olkin 2002). W USA postrzega się osoby dotknięte niepełnosprawnością jako dyskryminowaną mniejszość, która przedstawia swoje problemy we własnym imieniu, korzystając jednocześnie z pomocy osób sprawnych i specjalistów.

Podobnie jak model medyczny postrzegania niepełnosprawności, tak również model społeczny ma charakter redukcjonistyczny i zniekształca zjawisko. Z jednej bowiem strony przypisuje się z góry społeczeństwu (strukturze społecznej) postawę dyskryminacyjną, w szczególności jednostkom mającym perspektywę osobistą, niedotkniętym niepełnosprawnością i niezaangażowanym w rozwiązanie tego problemu, a z drugiej strony dokonuje się niemal całkowitej redukcji cielesnego wymiaru niepełnosprawności (Wiliński 2010), który to wymiar przecież nie zostaje usunięty, nawet jeśli uda się gdzieś zmodyfikować dyskryminujące postawy społeczne.

\section{Model interakcyjny}

Swoistym połączeniem obu modeli: medycznego i społecznego jest interakcyjny (albo rehabilitacyjny, funkcjonalny, ekonomiczny) model podejścia do niepełnosprawności (Nelson i in. 2017). Twierdzi się w nim, że niepełnosprawność jest pewnym stanem, który trzeba zaakceptować lub wyzwaniem, które należy podjąć, zwłaszcza w kontekście rynku pracy, a indywidualne dostosowanie niepełnosprawnych oznacza optymalne wykorzystanie ich zdolności funkcjonowania (Olkin 2002). Określa się ten model również jako ekonomiczny ze względu na postulat pracy zarobkowej osób dotkniętych niepełnosprawnością, stosownie do ich możliwości. W tym modelu zakłada się, iż wraz z rozwojem technologii będzie możliwe przezwyciężenie wszelkich form niepełnosprawności. Jednocześnie osoby 
z niepełnosprawnością otrzymują przekaz, że nie są akceptowane takie, jakie są, lecz ich niepełnosprawność musi zostać przezwyciężona. Podejście takie wywołuje w nich silny stres, gdyż są one podejrzewane o lenistwo i brak starań.

\section{Model moralny}

Wyróżniany przez wielu badaczy tzw. model moralny postrzegania niepełnosprawności (Woźniak 2008) nie jest jakimś czwartym modelem, odrębnym od zarysowanych powyżej, lecz podejściem, w którym następuje koncentracja na próbie filozoficznego zrozumienia, jakie mogą być przyczyny niepełnosprawności i jakie jest jej znaczenie dla osób, które zostały nią dotknięte, ewentualnie również dla ich bliskich. W modelu moralnym niepełnosprawność jest zazwyczaj ujmowana jako dotkliwa i należna kara za uczynki osoby nią dotkniętej (Wiliński 2010). Osoba z niepełnosprawnością zasłużyła sobie na ten stan i związane z nim cierpienie przez to, że naruszyła (świadomie lub nie) pewne normy moralne. Co więcej, to naruszenie nie musi być dokonane bezpośrednio przez osobę dotkniętą niepełnosprawnością, ale może również wynikać z działania jej rodziców, a konsekwencje zostają „przekazane na potomka”.

W modelu moralnym niepełnosprawność może być też postrzegana jako próba wiary osoby, która została nią dotknięta. Odmianą tego podejścia jest przekonanie i przekaz, płynące w odniesieniu do osoby z niepełnosprawnością, że nie została ona jeszcze uzdrowiona przez Boga, gdyż brak jej wystarczającej wiary. Często ona sama udaje się na rozmaite nabożeństwa i msze o uzdrowienie, czasem zabierają ją tam rodzice, na spotkania z cudotwórcami lub do tzw. miejsc świętych, aby pozbyć się niepełnosprawności.

W kolejnej wariacji modelu moralnego niepełnosprawność jest postrzegana jako bodziec, który może przyczynić się do duchowego rozwoju osoby, lub jako dar od Boga, będący wyrazem szczególnego wybrania i pozycji w społeczności wierzących, ewentualnie jako przejaw Bożego daru dla wspólnoty.

Według Woźniaka (2008), model moralny stracił obecnie swą aktualność, a odwołania do niego pojawiają się jedynie sporadycznie. Niestety, wydają się one czasami nadal obecne w środowiskach inspirowanych (źle pojmowaną) religijnością, również chrześcijańską, jeśli traktowana jest ona powierzchownie.

\section{Liderzy wspólnot chrześcijańskich wobec niepełnosprawności}

Stosunek do osób z niepełnosprawnością we wspólnotach kościelnych jest pochodną przyjmowania (otwarcie lub w sposób ukryty, świadomy lub nieświadomy) jednego ze wspomnianych modeli niepełnosprawności lub ich kombinacji, przy czym dominować zdaje się model moralny. Na uwagę zasługują tutaj wyniki badań jakościowych przeprowadzonych w USA wśród 19 pastorów różnych denominacji protestanckich (Keith i in. 2015). Choć uczestnicy badań mówili o genetycznych 
uwarunkowaniach niepełnosprawności, to kilku postrzegało ją jako efekt grzesznych działań, jak np. nadużywania alkoholu przez kobietę w ciąży, co skutkuje następnie alkoholowym zespołem płodowym u dziecka. Wielu pastorów stwierdziło, że niepełnosprawność to efekt ogólnego „upadku i zepsucia świata”, a jeden oznajmił, że to dzieło szatana. Niektórzy oświadczali, że Bóg nie chce wprawdzie niepełnosprawności, ale ją dopuszcza.

Co charakterystyczne, większość badanych liderów wspólnot chrześcijańskich akceptując elementy modelu moralnego - postrzega niepełnosprawność w kategoriach daru, okazji do duchowego wzrostu. Jeden z pastorów stwierdził, że ważne jest tylko, jak społeczeństwo odpowie na problem niepełnosprawności (model interakcyjny), inny - wtórując mu - orzekł, że niepełnosprawność to kulturowy test dla naszej miłości i szacunku wobec drugiego człowieka. Jeszcze inny - przechodząc na głębszy, duchowy poziom - podjął próbę swoistego unieważnienia niepełnosprawności, wpisując się w model społeczny: „Wszyscy jesteśmy ludźmi i mamy równe prawa. Nie jesteśmy jakąś pomyłką, lecz możemy modlić się słowami psalmisty: «Dziękuję Ci, że mnie stworzyłeś tak cudownie, godne podziwu są Twoje dzieła»" (Ps 139, 14).

Kolejny pastor oświadczył, że zdał sobie sprawę z własnej postawy dyskryminującej (ang. ableism) w odniesieniu do osób z niepełnosprawnością, wyrażającej się w przyjęciu medycznego modelu, czyli przekonania, że niepełnosprawność „powinna być wyleczona”. Pastor przyłapał się na modlitwie do Boga o cud uzdrowienia z niepełnosprawności pewnej członkini zboru, po czym zrozumiał, że to raczej on sam jest niepełnosprawny, a nie ta osoba. Był to dla niego moment pokornego uznania, że jego postrzeganie niepełnosprawności było błędne i aroganckie.

Moralny model postrzegania niepełnosprawności może być niestety wzmacniany we wspólnotach kościelnych przez kaznodziejstwo, liturgię, a przede wszystkim niektóre teksty biblijne, które miały i nadal mają decydujące znaczenie w kształtowaniu wspólnot chrześcijańskich, jak również ich kulturowych postaw wobec niepełnosprawności. Moim zamierzeniem nie jest dokonywanie egzegezy owych tekstów, lecz jedynie wskazanie na ich potencjalnie raniący charakter dla osób z niepełnosprawnością i deformujący podejście do nich przez „zdrowych” członków społeczności.

\section{Niepełnosprawność jako przyczyna wykluczenia z udziału w kulcie}

W niektórych tekstach Starego Testamentu odnoszących się do niepełnosprawności, tak fizycznej, jak i intelektualnej, można dostrzec oczywistą tendencję do stygmatyzacji, marginalizacji i ekskluzji osób z niepełnosprawnością ze wspólnoty kultycznej. W wielu miejscach niepełnosprawność wiązana jest $\mathrm{z}$ ubóstwem, niepowodzeniem i nieszczęściem, jednym słowem - z przekleństwem w podwójnym tego słowa znaczeniu: jako bycie przeklętym i jako bycie przekleństwem dla innych. W Księdze Kapłańskiej czytamy (21, 17-23): „Tak mów do Aarona: Ktokolwiek 
z potomków twoich według ich przyszłych pokoleń będzie miał jakąś skazę, nie będzie mógł się zbliżyć, aby ofiarować pokarm swego Boga. Żaden człowiek, który ma skazę, nie może się zbliżać - ani niewidomy, ani chromy, ani mający zniekształconą twarz, ani kaleka, ani ten, który ma złamaną nogę albo rękę, ani garbaty, ani niedorozwinięty, ani ten, kto ma bielmo na oku, ani chory na świerzb, ani okryty liszajami, ani ten, kto ma zgniecione jądra. Żaden z potomków kapłana Aarona, mający jakąś skazę, nie będzie się zbliżał, aby złożyć spalaną ofiarę Panu. On ma skazę - nie będzie się zbliżał, aby ofiarować pokarm swego Boga. Nie będzie bezcześcił moich świętości, bo Ja, Pan, jestem tym, który je uświęca!”.

We fragmencie tym chodzi wprost o wykluczenie osób dotkniętych niepełnosprawnością (jedną z 12 widocznych ułomności fizycznych) ze sprawowania funkcji ofiarniczych (kapłańskich) w Izraelu. Lewitom odpowiedzialnym za kult JHWH zabraniano bowiem składania ofiar, jeśli posiadali oni jakieś skazy (Stiker 2010). Aby służyć przy ołtarzu, kapłan musiał być zdrowy na ciele, przy czym doskonałość cielesna była zewnętrznym wyrazem wewnętrznej świętości (Tronina 2006, s. 315). Zakaz udziału w kulcie był rozszerzony również na inne osoby z defektami: „Nikt, kto ma zgniecione jądra lub odcięty członek, nie wejdzie do zgromadzenia Pana” oraz „Ktokolwiek pokona Jebusytów [...] oraz ślepych i kulawych nienawistnych dla duszy Dawida... [ten będzie wodzem]”. Stąd pochodzi powiedzenie: „Ślepiec i kulawy nie wejdą do wnętrza domu" (2 Sm 5,8$)$.

Powyższe teksty były używane w chrześcijaństwie przez władze kościelne do wykluczania osób z niepełnosprawnością ze sprawowania kościelnych urzędów. W Kościele Rymskokatolickim odmawiano osobom dotkniętym dysfunkcjami aż do XX wieku święceń kapłańskich. Na przykład na synodzie Diecezji Kolońskiej w 1954 uchwalono, aby kandydatom „chorowitym, słabym intelektualnie lub obciążonym genetycznie odpowiednio wcześnie uniemożliwić profesję kapłańską" (Liedtke 1996, s. 29).

Szczególnie dobitnie i złowrogo brzmi przekaz zawarty w tekście z Księgi Kapłańskiej, że osoba z widoczną niepełnosprawnością doprowadziłaby do zbezczeszczenia rzeczy świętych poprzez sam fakt zbliżenia się do nich. Trzeba dodać, że choć wymienione wyżej teksty oddzielały osoby dotknięte różnymi dysfunkcjami od oficjalnego kultu religijnego (ofiarniczego), odbywającego się w miejscach świętych, to nie przesądzały o możliwości ich wewnętrznej relacji z Bogiem, wyrażającej się w przestrzeganiu Jego przykazań: „Czyż milsze są dla Pana całopalenia i ofiary krwawe od posłuszeństwa głosowi Pana? Właśnie, lepsze jest posłuszeństwo od ofiary, uległość - od tłuszczu baranów (1 Sam 15, 22). Fizyczne oddzielenie od wspólnoty czczącej Boga było jednak widoczne i oczywiste, co więcej, „wszyscy synowie Izraela” byli odpowiedzialni za przestrzeganie i wykonanie tych postanowień (Tronina 317). To postrzeganie niepełnosprawności jako potencjalnego zagrożenia dla sfery sacrum zaciążyło zapewne na wykluczającym niekiedy sposobie postrzegania takich osób przez wspólnoty chrześcijańskie (Kochanowicz 2008). 


\section{Niepełnosprawność jako kara za grzechy}

W wielu tekstach Starego Testamentu niepełnosprawność jawi się jako kara za grzechy. W Księdze Powtórzonego Prawa znajduje się długie przemówienie, w którym Bóg grozi ludziom wielkimi nieszczęściami, jeśli nie usłuchają jego głosu: „Jeśli nie usłuchasz głosu Pana, Boga swego, i nie wykonasz pilnie wszystkich poleceń i praw, które ja dzisiaj tobie daję, spadną na ciebie wszystkie te przekleństwa i dotkną cię". W tym miejscu następuje długa lista problemów zdrowotnych czekających grzeszników: „Pan dotknie cię wrzodem egipskim, hemoroidami, świerzbem i parchami, których nie zdołasz wyleczyć. Pan dotknie cię obłędem, ślepotą i niepokojem serca" (Pwt 28, 27-28). Słuchacze tego wywodu mogli (i zapewne nadal mogą) sądzić, iż niepełnosprawność, np. w postaci uszkodzonego wzroku lub zaburzeń psychicznych (szał, ślepota i pomieszanie zmysłów), jest prostą konsekwencją braku przestrzegania przykazań.

Inny przykład można odnaleźć w Psalmie 137, 5-6: „Jeruzalem, jeśli zapomnę o tobie, niech uschnie moja prawica! Niech język mi przyschnie do podniebienia”. W tym przypadku brak zdolności mówienia może być interpretowany jako piętno wynikające z zapomnienia o sprawach Bożych. Również w tekście z proroka Micheasza wraca idea niepełnosprawności jako efektu karzącego działania Boga: „W owym dniu - wyrocznia Pana - zbiorę chromych, zgromadzę wygnańców i tych, których utrapiłem" (Mi 4, 6). Logika jest ciągle ta sama: niepełnosprawność jest nieszczęściem, w idealnej przyszłości nie będzie dla niej miejsca, bo jest ona zjawiskiem czysto negatywnym.

Oczywiście Objawienie Boże podlega rozwojowi, dlatego przekonanie obecne w wielu tekstach Starego Testamentu, że niepełnosprawność (czy szerzej cierpienie) jest karą ze strony Boga za grzechy ludzkie, zostało istotnie zakwestionowane w Księdze Hioba, który - doświadczając niewymownego cierpienia - musiał zmierzyć się ze swymi trzema przyjaciółmi przypominającymi mu, iż to Bóg odpłaca złem za zło. W postaci sprawiedliwego Hioba stało się jednak oczywiste, że choć cierpienie może być karą, kiedy wiąże się z jakąś winą, to nie zawsze nim jest. Niekiedy przybiera postać niezawinionego cierpienia, będącego tajemnicą (Salvifici Doloris, 11)

W tekstach Nowego Testamentu powiązanie niepełnosprawności z grzesznością nie zostaje zasadniczo rozerwane, lecz zniuansowane, a następnie sproblematyzowane na nowo. Osoby z niepełnosprawnością nie są wprawdzie wprost wykluczone z oficjalnego kultu jak w Starym Testamencie, co więcej kładzie się duży nacisk na spotkania Jezusa $\mathrm{z}$ różnymi osobami dotkniętymi niepełnosprawnością, ale są one postrzegane głównie jako szczególne przypadki ukazania się boskiej mocy i chwały (Bengtssone 2014).

W Ewangelii wg św. Łukasza Jezus poucza osoby wydające ucztę (Łk 14, 13-14), aby zapraszały na nią: „ubogich, ułomnych, chromych i niewidomych”, czyli cztery kategorie osób wykluczonych z kultu sprawowanego w świątyni, którym 
odmawiano wspólnoty z Bogiem (2 Sm 5,8). Jezus nawiązuje tu do obietnic Izajasza (Iz 29, 18-19), że w czasach mesjańskich ubodzy, głusi, niewidomi, kulawi i niemi oraz wszyscy upokarzani i usuwani na margines społeczeństwa otrzymają zdrowie i będą mogli zbliżyć się do Boga z czystym sercem (Mickiewicz 2012, s. 126). Jeśli gospodarz zaprosi takich właśnie gości, to będzie błogosławiony, gdyż goście z niepełnosprawnością nie będą mogli się mu odwdzięczyć. Przesłanie tego tekstu jest ambiwalentne: $z$ jednej strony pojawia się zalecenie, aby osobom $z$ niepełnosprawnością przyznać lepsze miejsce w społeczeństwie, wchodzić z nimi w interakcje, z drugiej zaś przyjmuje się za oczywiste, że osoby te mają mniej do zaoferowania innym na poziomie społecznym, co z kolei - paradoksalnie - może zapewnić im wyższy status w kategoriach religijnych.

W Ewangelii Marka (2,1-12) znajduje się opowieść o paralityku, czyli prawdopodobnie osobie dotkniętej tetraplegią, którą czterech ludzi spuściło przez dach do pomieszczenia, gdzie nauczał Jezus otoczony przez tłumy. Ta opowieść była często interpretowana $\mathrm{w}$ historii jako opowieść o heroicznych, zaangażowanych i pełnych wiary uczniach i kalekim grzeszniku. Zdaje się to potwierdzać pierwsze zdanie Jezusa skierowane do paralityka, obiecujące mu uleczenie duchowe: „Synu, odpuszczają Ci się twoje grzechy”. Dopiero drugie zdanie niesie ze sobą uzdrowienie fizyczne: „wstań, weź swoje łoże i chodź”. Choć niepełnosprawność nie jest w tym przypadku ukazana jako prosta konsekwencja grzechu, to niewątpliwie jest sugerowana ścisła korelacja między niepełnosprawnością a winą moralną. Z faktu odpuszczenia grzechów nie wynika wprawdzie, że chory był grzesznikiem we współczesnym tego ujęciu, lecz to, że świat żydowski widział chorobę - zwłaszcza poważniejszą - w kontekście grzechu (Langkammer 1977, s. 109).

Związek przyczynowo-skutkowy między grzesznością i niepełnosprawnością powraca w opowieści z Ewangelii św. Jana o uzdrowieniu człowieka, który nie mógł chodzić, zapewne paralityka (J 5, 1-16). Wraz z innymi niewidomymi, chromymi i sparaliżowanymi należał on do ludzi, którym ułomność nie pozwalała korzystać z pełni człowieczeństwa, którzy przebywali poza terenem świątynnym, poza sferą sacrum, zepchnięci na margines społeczny przez system religijno-społeczny (Mędala 2010, s. 5020). Jezus rzekł do chromego po dokonaniu jego uzdrowienia: „Oto wyzdrowiałeś. Nie grzesz już więcej, aby ci się coś gorszego nie przydarzyło”. Współcześni słuchacze mogą te słowa zrozumieć następująco: „twoje trudności motoryczne, twoja niepełnosprawność ruchowa była wynikiem twoich grzechów, obecnie została uleczona, bo grzech zniknął”. To przesłanie jest szczególnie niebezpieczne, gdyż osoby z niepełnosprawnością mogą sądzić, że skoro nie doznały jeszcze uzdrowienia ze swojej dysfunkcji, to znaczy, że nadal trwają w grzechu, czyli są odrzucone przez Boga. Oczywiście to, iż Jezus pochyla się nad osobą wykluczoną ze sfery sacrum ze względu na swą niepełnosprawność i włącza ją we wspólnotę, jest nowym, ważnym wezwaniem dla jego uczniów-chrześcijan.

Przekonanie o związku między grzechem a niepełnosprawnością znalazło wyraz w okrutnym zabobonie, który pojawił się w średniowiecznej Europie mniej więcej 
w X wieku, mianowicie w wierze w tzw. odmieńce (niemieckie: Wechselbalg), podrzucane kobiecie znajdującej się w połogu przez demoniczne moce (boginki, karły, druidy lub czarownice) w zamian za jej własne jeszcze nieochrzczone dziecko (Piaschewski 1935). Odmieniec był postrzegany jako dziecko czarownicy lub nawet samego diabła. Niestety, za takowe uważano często dzieci z widocznymi deficytami rozwojowymi (jak np. wodogłowie, mózgowe porażenie dziecięce, głuchota), co prowadziło do ich izolacji, a najczęściej po prostu do ich zabicia. Osiągnęło to swój szczyt w epoce procesów czarownic, od XV do XVII wieku, ale udokumentowane są przypadki uśmiercania zdeformowanych noworodków jeszcze w XIX wieku. Niestety, również Marcin Luter podzielał poglądy swojej epoki na temat odmieńców, gdyż pisał: „takie odmieńce supponit Satan in locum verosum filiorum [kładzie Szatan w miejsce prawdziwych dzieci] i plaget [dręczy] w ten sposób ludzi. Ponieważ szatan ma władzę podmieniania dzieci, i człowiekowi zamiast jego dziecka wkłada do kołyski diabła, który nie myśli, tylko żre i pije" (Liedtke 1996, s. 28). Luter był za natychmiastowym zabijaniem odmieńców, gdyż uważał ich tylko za „kupę mięsa pozbawioną duszy”.

\section{Niepełnosprawność jako znak Bożego wybrania}

Kolejny schemat postrzegania osób z niepełnosprawnością w Biblii - to interpretowanie ich niepełnosprawności jako znaku wybrania przez Boga, i wiążącej się z tym okazji do uszlachetnienia człowieka. Ewangelista Jan opisuje scenę, w której Jezus (J 9, 1-14) uzdrawia człowieka niewidomego od urodzenia (Brodie 1993, s. 346). Wychowani na Biblii hebrajskiej uczniowie pytają Jezusa wprost: „kto zgrzeszył, że się urodził niewidomym - on czy jego rodzice?”. Jezus neguje najpierw związek przyczynowo-skutkowy między grzechem a niepełnosprawnością, mówiąc, że nikt nie zgrzeszył: ani on, ani jego rodzice. Następnie wyjaśnia, że niepełnosprawność tego człowieka stała się okazją do ujawnienia się w jego życiu szczególnej, bezpośredniej interwencji boskiej: „[stało się tak], aby się na nim objawiły sprawy Boże”. Niepełnosprawność jest tu ukazana jako swoisty znak wybrania, możliwość nawiązania nadzwyczajnej relacji z Bogiem.

Podobnie ujmuje tę kwestię Apostoł Paweł, który pisze w Drugim Liście do Koryntian o swojej tajemniczej dolegliwości fizycznej: „Aby zaś nie wynosił mnie zbytnio ogrom objawień, dany mi został oścień dla ciała, wysłannik szatana, aby mnie policzkował - żebym się nie unosił pychą. Dlatego trzykrotnie prosiłem Pana, aby odszedł ode mnie, lecz [Pan] mi powiedział: «Wystarczy ci mojej łaski. Moc bowiem w słabości się doskonali»" (2 Kor 12, 7-10). Ta dotkliwa dolegliwość apostoła, różnie interpretowana, np. jako uszkodzenie wzroku (Hisey i in. 1961), jest określana przez Pawła bulwersującym terminem: wysłannik szatana. Jednocześnie apostoł pojmuje swój defekt jako wyraz Boskiej łaskawości, który go uszlachetnia. Cierpienie jest w tym przypadku interpretowane jako swoisty dar od Boga. Taka koncepcja wpłynęła niepomiernie na chrześcijańską teologię wskazującą na 
uświęcającą lub uszlachetniającą moc cierpienia. Historia starotestamentowego Hioba lub nowotestamentowego cierpiącego Łazarza - to wyraz przekonania, że fizyczne dolegliwości i dysfunkcje są znakiem Bożego wybrania. Prowadzą one do oczyszczenia i udoskonalenia sprawiedliwych, którzy po zwycięskim przejściu ziemskich prób dostępują nagrody w niebie. Potwierdza istnienie takiego spojrzenia Erving Goffman w książce Piętno (2007, s. 42): „Doznawane cierpienie jednostka może postrzegać jako zamaskowane błogosławieństwo, szczególnie w kontekście szeroko rozpowszechnionych wyobrażeń o związku zachodzącym między cierpieniem a życiową mądrością. Taka osoba jest przekonana, że wiele nauczyła się dzięki cierpieniu, czego nie zdobyłaby bez niego".

Idea uszlachetniającego cierpienia może być swoistym zagrożeniem dla osób z niepełnosprawnością, gdyż może wzmacniać ich pasywność, wywoływać postawę rezygnacji, jako właściwą odpowiedź na bycie „testowanym” przez Boga. Równocześnie idea uszlachetniającego cierpienia pomaga w akceptowaniu przez osoby z niepełnosprawnością barier wznoszonych przez społeczeństwo oraz w naznaczonej subtelnym resentymentem akceptacji swego drugorzędnego statusu w społeczeństwie i w Kościele.

\section{Niepełnosprawność jako wyzwanie dla wspólnoty chrześcijańskiej}

Następnym motywem biblijnym, który wpływa na kształt relacji między zdrowymi i niepełnosprawnymi członkami wspólnot chrześcijańskich, jest wezwanie do jałmużny, wsparcia potrzebujących, czyli do działalności charytatywnej. Jest to odmiana interakcyjnego modelu niepełnosprawności. W starożytnych kulturach jałmużna była środkiem utrzymującym przy życiu osoby, które nie mogły zadbać o siebie samodzielnie (Jones 2016). Zwyczaj codziennego rozdawania jałmużny był praktykowany nadal we wspólnotach chrześcijańskich w odniesieniu do osób zmarginalizowanych, włączając $w$ to tych, którzy nie mogli sami zadbać o siebie, np. wdowy (Dz 6, 1-6). W wielu miejscach Nowego Testamentu zwraca się uwagę na związek między działalnością charytatywną a uzdrowieniem. Przykładem może być opowieść o człowieku niepełnosprawnym leżącym przed wejściem do Świątyni Jerozolimskiej (Dz 3, 1-10). Gdy poprosił on Piotra i Jana o jałmużnę, ci zamiast ofiarować mu pieniądze - uleczyli go. Po odzyskaniu władzy w nogach człowiek ten mógł wejść razem z apostołami do świątyni i chwalić Boga: dopóki był niepełnosprawny, pozostawał wykluczony z udziału w kulcie, z dostępu do sfery sacrum (Barrett 1994, s. 174-185).

W instytucjach charytatywnych organizowanych przez wspólnoty chrześcijańskie łączono często pomoc charytatywną z leczeniem, powstawały liczne szpitale, przytułki - również dla osób z niepełnosprawnością. Instytucje te zapewniały humanitarną opiekę, pomoc medyczną oraz wsparcie finansowe. Ich twórcy inspirowali się zapewne tekstami biblijnymi, m.in. przypowieścią o miłosiernym Samarytaninie (Łk 10, 30-37), stając się „bliźnimi” zranionych, niepełnosprawnych, 
chorych, niosącymi pomoc w cierpieniu, jakiekolwiek by ono było. Jednocześnie, w sposób niezamierzony, efektem działań wielu stowarzyszeń charytatywnych była środowiskowa i społeczna izolacja osób z niepełnosprawnością od wspólnot chrześcijańskich (Risse 1999).

\section{Zakończenie}

Te cztery wskazane motywy przewodnie: niepełnosprawność jako powód wykluczenia ze wspólnoty kultycznej, niepełnosprawność jako efekt grzeszności, niepełnosprawność jako źródło uszlachetnienia jednostki, niepełnosprawność jako impuls dla wspólnoty do działalności charytatywnej opisują - w moim przekonaniu - główne, choć nie w równym stopniu ważne bariery, które utrudniają osobom z niepełnosprawnością pełne włączenie się w życie wspólnoty chrześcijańskiej. Są oczywiście jeszcze inne przeszkody, które warto by dokładnie przeanalizować, np. kwestia powątpiewania, czy w odniesieniu do osób z niepełnosprawnością można użyć stwierdzenia, że są Imago Dei, obrazem Boga, czyli - jak to określa Biblia zostały stworzone na obraz i podobieństwo Boże. W historii było wiele prób interpretowania tego stwierdzenia, które uznawano za problematyczne ze względu na grzeszność człowieka, będącą wszak zaprzeczeniem Bożej doskonałości. Ojcowie Kościoła mówili o zagubionym zewnętrznym podobieństwie do Boga, ale przetrwałym duchowym, Reformatorzy skłaniali się do przyjmowania podobieństwa „wykrzywionego" przez grzech, natomiast od czasów renesansu postrzega się owo podobieństwo (nie bez dyskusji jednak) jako teologiczne uzasadnienie osobowej godności człowieka. Problem jednak tkwi w tym, iż w wielu próbach opisania owej osobowej godności (niezależnie od tego, czy akcentuje się w niej klasycznie: świadomość, wolność i odpowiedzialność, czy też możliwość nawiązywania relacji lub partycypacji w życiu społecznym) wykluczeni z kręgu osób pozostają nadal ludzie dotknięci szczególnie wyrazistą niepełnosprawnością, np. sprzężoną (Kochanowicz 2016; Maliszewska 2018). Może należałoby zatem pójść za inspiracją płynącą z pism Angelusa Silesiusa czy Fryderyka Feuerbacha i promować inny obraz Boga - na wzór człowieka słabego, dotkniętego poważnymi dysfunkcjami?

Co jednak zrobić z tekstami biblijnymi, które zawierają w sobie raniące przesłanie? Trudno byłoby je wykreślić z Biblii, gdyż jest to święta księga Żydów i chrześcijan, będąca relacją z objawiania się Boga swojemu ludowi. Nie pozostaje zatem nic innego, jak poddawać je pogłębionej egzegezie (choć wśród chrześcijańskich głosicieli słowa niewielu jest doktorów in re biblica), czyli podkreślać ich historyczne uwarunkowania: to, że powstawały w ramach kultury, w której łączono powszechnie kwestie zdrowia, choroby, niepełnosprawności z działalnością bóstw i demonów, a każdego człowieka uważano za część grzesznej ludzkości ( $\mathrm{Rz} 3$, 9-10; 3, 23; Łk 11, 4). W tym kontekście osoby z niepełnosprawnością były umieszczane w ramach pewnej oczywistej i wszystkich ogarniającej „normalności”. 
Niestety, choć w ostatnich dziesięcioleciach uznano generalnie problematyczność wielu wypowiedzi biblijnych, np. w odniesieniu do kobiet, to negatywne przedstawianie osób z niepełnosprawnością jest nadal traktowane zbyt lekko, ignorowane, lub - jak to się niestety zdarza - uważane za trafne i odpowiadające naszemu doświadczeniu. Choć rozwinęła się teologia feministyczna, teologia uciśnionych, teologia wyzwolenia, to ciągle brakuje dopracowania sensownej teologii niepełnosprawnych. Tymczasem powinna być ona integralną częścią życia chrześcijan oraz teologicznej refleksji na tym życiem. Próby tworzenia takiej teologii były podejmowane w Stanach Zjednoczonych, m.in. przez Nancy Eiesland z Emory University w Atlancie. Niestety, przedwczesna śmieć tej socjolożki i protestanckiej teolożki, dotkniętej znaczną niepełnosprawnością, autorki książki pt. The Disabled God (1994) sprawiła, iż tematyka ta zeszła na margines, choć wiele interesujących treści zawiera nowsza publikacja Theology and Experience of Disability, przygotowana przez międzynarodową grupę protestanckich teologów, pracowników socjalnych i zaangażowanych chrześcijan. Cenną publikacją przygotowującą przedpole do tworzenia nowych teologii niepełnosprawności jest praca zbiorowa, w której przedstawiono podejście do tych kwestii u takich postaci, jak: Augustyn, Ojcowie Kapadoccy, Julianna z Norwich, Marcin Luter, Dietrich Bonhoeffer, Karl Barth, różni współcześni teologowie feministyczni, Jean Vanier i Stanley Hauerwas (Picard, Habets 2016). Na polskim gruncie ważne są prace Katarzyny Lausch, Elżbiety Bednarz, Anety Kochanowicz oraz Doroty Krzemińskiej.

Trzeba przede wszystkim zerwać $z$ odmianą moralnego modelu niepełnosprawności, w której jest ona łączona w sposób niezróżnicowany z winą, karą za grzech, i przyjąć, że niepełnosprawność jest istotnym rysem każdej ludzkiej egzystencji (choć oczywiście nie z równym natężeniem i czasową ekstensywnością). Chodzi bowiem o to, aby wspólnoty chrześcijańskie nie rezygnowały ze szczególnej mocy osób z niepełnoprawnością (wyrażanej paradoksalnie w ich słabości).

Cennym źródłem dla pogłębionego spojrzenia na właściwe miejsce osób z niepełnosprawnością we wspólnotach chrześcijańskich może być przejmujący List apostolski Jana Pawła II „Salvifici doloris”. Choć jego treść dotyczy szerszej tematyki, mianowicie „chrześcijańskiego sensu ludzkiego cierpienia”, to zawarte w tekście analizy wydają się trafne w odniesieniu do wielu osób z niepełnosprawnością, doświadczających różnych form cierpienia, również takich, które pochodzą od „upośledzającego społeczeństwa”. Rzeczywistość cierpienia opisana w tym tekście (a dla naszych rozważań mutatis mutandis niepełnosprawności) pozostanie zawsze enigmą, niewypowiedzianą tajemnicą. Osoby cierpiące (niepełnosprawnych) zdaje się postrzegać papież jako doświadczających - jako członków wspólnoty - zbawczej obecności Boga, nieróżniącej się istotnie od Jego obecności w sprawowanych sakramentach i głoszonym Słowie. Cierpienie (niepełnosprawność?) - pisze papież „bardziej niż cokolwiek innego toruje drogę łasce przeobrażającej dusze ludzkie. To ono, bardziej niż cokolwiek innego, uobecnia moce Odkupienia w dziejach ludzkości" (Salvifici doloris, 27). Pisze to autor w tekście wydanym w roku 1984, 
czyli po doświadczeniu długiej rekonwalescencji koniecznej po zamachu na jego życie. Zapewne nie przypuszczał wówczas, iż pod koniec swego życia - trwając w samym centrum wspólnoty - stanie się osobą niedołężną, poruszającą się na wózku inwalidzkim, z chorobą Parkinsona, przebytym zabiegiem tracheotomii, wreszcie osobą niemą, w sumie - osobą z widoczną dla każdego niepełnosprawnością.

Teologiczne, a następnie praktyczne, „umieszczenie” osób z niepełnosprawnością w samym centrum wspólnot chrześcijańskich będzie dla ich członków szansą nie tylko na zachowanie ewangelicznego wymiaru ich społeczności, lecz wręcz na odnalezienie przez nich pełni człowieczeństwa. „Człowiek [...] nie może odnaleźć się w pełni inaczej, jak tylko poprzez bezinteresowny dar z siebie samego" (Gaudium et spes, 24).

\section{Bibliografia}

Annandale N. H., Carter E. W. (2014). Disability and theological education: A North American study. „Theological Education”, nr 48, s. 83-102.

Barrett C.K. (1994). A Critical and Exegetical Commentary on the Acts of the Apostles. T. 1. Edinburgh: T\&T Clark.

Bednarz E. (2004). Katechetyka: edukacja religijna dziecka głębiej upośledzonego umysłowo z uwzględnieniem zielonoświątkowego profilu konfesyjnego. Warszawa: Instytut Wydawniczy Agape.

Bengtssone S. (2014). The two-sided coin - disability, normalcy and social categorization in the New Testament. "Scandinavian Journal of Disability Research”, nr 7 (16), s. 280-292.

Brodie T. L (1993). The Gospel According to John. A Literary and Theological Commentary. New York: Oxford University Press.

Dokument Stolicy Apostolskiej na Międzynarodowy Rok Osób Upośledzonych (1981). „L'Osservatore Romano”, wyd. polskie, nr 3.

Eiesland N. (1994). The Disabled God: Toward a Liberatory Theology of Disability. Nashville: Abingdon Press.

Gaventa W. C. (2016). Preaching disability: The whole of Christ's body in word and practice. „Review and Expositor”, nr 113, s. 225-242.

Goffman E. (2007). Piętno. Rozważania o zranionej. Gdańsk: GWP.

Healey L., Humphreys C., Howe, K. (2013). Inclusive domestic violence standards: Strategies to improve interventions for women with disabilities? „Violence Vict”, nr 28 (1), s. 50-68.

Hisey A., James S., Beck P. (1961). Paul's “Thorn in the Flesh”: A Paragnosis, „Journal of Bible and Religion”, nr 2, s. 125-129.

Jan Paweł II (1984) List apostolski „Salvifici doloris”. Watykan.

Jones D. J. (2016). Alms: Charity, Reward, and Atonement in Early Christianity. Waco: Baylor University Press. 
Keith J. M., Bennetto L., Rogge R. D. (2015). The relationship between contact and attitudes: Reducing prejudice toward individuals with intellectual and developmental disabilities. „Research in Developmental Disabilities”, nr 47, s. 14-26.

Kochanowicz A. (2008). Wymiar sacrum w edukacji dziecka z głębokg wieloraka niepetnosprawnościa. W: Sekułowicz M., Kruk-Lasocka J., Kulmatycki L. (red.). Psychomotoryka - ruch pełen znaczeń. Wrocław: Wydawnictwo Naukowe DSW, S. 259-270.

Kochanowicz A. (2016). Dziecko w śpiączce. Sens życia. Sens troski. Łódź: Wydawnictwo Palatum.

Krzemińska D. (2013). Szkic do rozważań o życiu religijnym i doświadczaniu wiary przez osoby dorosłe z niepełnosprawnościa intelektualna. "Niepełnosprawność”, nr 10, s. 112-132.

Langkammer H. (1977). Ewangelia według św. Marka. Poznań-Warszawa: Pallotinum.

Lausch K. M. (1987). Teoretyczne podstawy katechizacji osób głębiej upośledzonych umysłowo. Warszawa: ATK.

Liedtke M. (1996). Behinderung - Anthropologie und pädagogische Aspekte. W: Liedtke M. (red.). Behinderung als pädagogische und politische Herausforderung. Historische und systematische Aspekte. Bad Heilbrunn: Verlag Julius Klinkhardt, S. 21-31.

Maliszewska A. (2018). W petni ludzie. „Studia Bobolanum”, nr 2, s. 45-76.

Mędala S. (2010). Ewangelia według świętego Jana, rozdziały 1-12. Częstochowa: Edycja Świętego Pawła.

Mickiewicz F. (2012). Ewangelia według świętego Łukasza, rozdziały 12-24. Częstochowa: Edycja Świętego Pawła.

Nelson J. R., Wang M.-C., Haagenson L. R. (2017). Inclusive, Culturally Competent Practices for Christian Faith Leaders in Responding to IPV Survivors with Disabilities. W: Johnson A., Nelson J. R., Lund E. L. (red.). Religion, Disability, and Interpersonal Violences. New York: Springen.

Olkin R. (2002). Could you hold the door for me? Including disability in diversity. „Cultural Diversity and Ethnic Minority Psychology”, nr 2, s. 130-137.

Piaschewski G. (1935). Der Wechselbalg. Ein Beitrag zum Aberglauben der nordeuropäischen Völker. Breslau: Maruschke und Berendt.

Pismo Święte Starego i Nowego Testamentu (2012). Poznań: Wydawnictwo Pallotinum.

Risse G. B. (1999). Mending Bodies, Saving Souls: A History of Hospitals. New York: Oxford University Press.

Sobór Watykański II. (2005). Konstytucja duszpasterska o Kościele w świecie współczesnym. Warszawa: Pallotinum.

Stiker H.-J. (2010). Disability in the Hebrew Bible. S.M. Olyan. Interpreting mental and physical differences. Cambridge University Press. (2008). „ALTER - European Journal of Disability Research" (New York), nr 3, s. 222-228. 
Theology and the experience of disability: interdisciplinary perspectives from voices down under. (2016). Picard A., Habets M. (red.) London: Routledge, Taylor \& Francis Group.

Tronina A. (2006). Księga kapłańska. Częstochowa: Edycja Świętego Pawła.

Wiliński M. (2010). Modele niepetnosprawności: indywidualny - funkcjonalny społeczny. W: Brzezińska A., Kaczan R., Smoczyńska K. (red.). Diagnoza potrzeb i modele pomocy dla osób z ograniczeniami sprawności. Warszawa: Wydawnictwo Naukowe Scholar, s. 15-59.

Woźniak Z. (2008). Niepetnosprawność i niepetnosprawni w polityce społecznej. Społeczny kontekst medycznego problemu. Warszawa: Wydawnictwo Naukowe SWPS.

Yong A. (2011). The Bible, disability, and the Church: A new vision of the People of God. Grand Rapids: William B. Eerdmans.

\title{
BARRIERS TO THE INCLUSION OF PEOPLE WITH DISABILITIES IN CHRISTIAN COMMUNITIES
}

\begin{abstract}
The aim of the article is to indicate selected biblical texts that contribute to build the barriers that prevent the full inclusion of people with disabilities in Christian communities. In the Scriptures, disability is often perceived as a reason for exclusion from the worship community, the result of sinfulness or a trigger to dignify a person, or as an opportunity to organize charitable activities. In any case, the position of a person with a disability is perceived as unusual. If biblical texts are read superficially, there is a danger of denying people with a disability a mature relationship with God and full participation in the life of the community. The author postulates the development of theology that would appreciate the special contribution of people with disability to the Christian community and grant them a central rather than peripheral position.
\end{abstract}

Keywords: disability; models of disability; inclusion; Christian communities; theology of disability.

Jerzy Kochanowicz - doktor habilitowany, zatrudniony na stanowisku profesora w Katedrze Pedagogiki Akademii WSB w Dąbrowie Górniczej. Jest z wykształcenia pedagogiem (habilitacja na UMK w Toruniu) oraz teologiem (doktorat w Philosophisch-Theologische Hochschule Sankt Georgen we Franfkurcie n. Menem). W pracy badawczej koncentruje się na historii edukacji oraz relacjach między pedagogiką a religią. Adres korespondencyjny: ul. Cieplaka 1c, 41-30o Dąbrowa Górnicza. Adres e-mailowy: jkochanowicz@wsb.edu.pl. 